UDC 656.13

DOI: 10.15587/2706-5448.2021.235469

Article type «Reports on Research Projects»

\section{Oleksandra Humeniuk, Oleksij Shapovalov}

\title{
TRANSPORT MODELING IN THE DEVELOPMENT OF A COMPLEX TRANSPORT SCHEME ON THE EXAMPLE OF THE CITY OF KYIV (UKRAINE)
}

The object of research is a complex transport scheme using the example of the city of Kyiv (Ukraine). The comprehensive transport scheme of the city of Kyiv provides for a variant design of the city's transport system. In transport planning and design, for a qualitative assessment of planning decisions, predictive transport models of cities are most often used, which describe the macroscopic parameters of the traffic flow. The proposed options were tested on a transport model. The main task of this model is the modeling of transport correspondence, where the volume of traffic by public transport is about 80-90\% of the total volume of traffic. For this, a model was developed, with the help of which the level of loading of the main network, the volume of transport work, and the total number of passengers carried by public transport were analyzed. When choosing the optimal option, let's took into account such parameters as the average speed of the traffic flow, general transport delays, and the total number of passengers transported by public transport. As well as the average distance of travel, the average time for the implementation of transport correspondence on public transport, the cost of unproductive loss of time by residents of the city, and so on.

Based on the results of transport modeling, the optimal option for the development of the city's transport system was selected, which provides for the completion of the construction of existing road transport infrastructure facilities, the construction and development of the backbone network, systems outside the street rail transport, and optimization of the public transport route network. The complex transport scheme of the city of Kyiv, which was created using modern technologies in the field of transport modeling, allows to analyze and determine the effectiveness of the implementation of various measures for the development of the city's transport infrastructure. Transport modeling has shown the feasibility of providing initial data for the feasibility study of investment projects, the arrangement of road transport infrastructure facilities, the improvement of traffic management schemes, the arrangement of new public transport routes.

Keywords: macromodeling of traffic flows, transport model, transport planning, backbone network, transport infrastructure.

\section{How to cite}

Humeniuk, O., Shapovalov, O. (2021). Transport modeling in the development of a complex transport scheme on the example of the city of Kyiv (Ukraine). Technology Audit and Production Reserves, 3 (2 (59)), 51-54. doi: http://doi.org/10.15587/2706-5448.2021.235469

\section{Introduction}

Making informed decisions on the development of transport infrastructure is a topical issue for many cities in the world. Modern transport problems, the lagging pace of development of the backbone network and the public transport system worsen the conditions of movement of residents. This problem is especially acute in large, large and large cities [1,2].

In this paper, let's consider the issues of an integrated approach to the development of the city's transport system and the choice of effective tools for solving urgent transport problems using the example of the city of
Kyiv (Ukraine). The backbone network for the city was designed for the level of motorization of 200-250 cars per 1000 inhabitants, although today in the country as a whole this figure is $250-300$ cars per 1000 inhabitants. In Kyiv, according to the calculations of specialists of the Communal Organization «Kyivgenplan», the figure exceeded the figure of 370 cars per 1000 inhabitants [2, 3].

With the aim of rational development of traffic in cities, according to the new state building codes for planning and development of territories, an integrated transport scheme (ITS) is being developed as a separate document for settlements with a population of more than 100 thousand people during the billing period [3]. 
By order of the Department of Urban Planning and Architecture, the Communal Organization «Kyivgenplan» is developing a «Comprehensive transport scheme for the city of Kyiv as part of an integrated plan for the development of the transport infrastructure of the city of Kyiv and its suburban area» (ITS). The main task of the ITS development is to improve the transport system of the city of Kyiv in terms of the development of the road network, improve the public transport system, provide proposals for organizing bicycle infrastructure, and the like. The work on the ITS development is carried out in accordance with the approved schedule. At the moment, the stage of clarification and updating of the initial data for the existing transport model of the city has been completed, including up-to-date information on the distribution of the population and its demographic situation, the graph of the road network, and the operation of public transport. Also, options were developed for the development of the city's transport infrastructure for different stages of implementation, taking into account the prospective population and places of employment.

Therefore, it is relevant to study the application of transport modeling in drawing up a program for the development of the city's transport infrastructure. This study will be especially interesting for cities that do not have developed transport models. So, the object of research is a complex transport scheme using the example of the city of Kyiv (Ukraine). The aim of research is to study the features of transport modeling.

\section{Methods of research}

To analyze the operation of the city's transport network, the following groups of transport models are used:

1) forecast;

2) imitation;

3) optimization.

In 1960, the UK created the first transport model based on the principles of computer modeling of the distribution of traffic flows. City transport planning uses predictive transport models. A special condition for the development of CTS is the use of the transport model of Kyiv and its suburban area, made in the software package PTV Visum [4]. The load level of the backbone network in the transport model of the city of Kyiv are shown in Fig. 1.

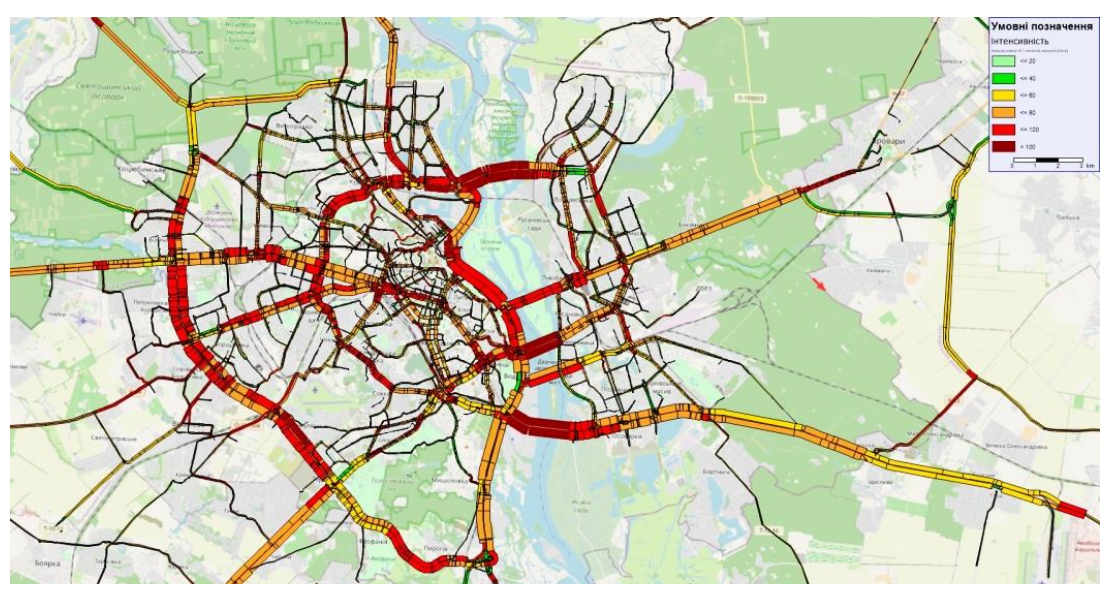

Fig. 1. Transport model of the city of Kyiv
Macromodeling of traffic flows is an effective tool for a qualitative assessment of the functioning of the city's transport system as a whole, determination of the rational arrangement of new objects of the road network, and optimization of the public transport system. Transport modeling helps to analyze the level and redistribution of traffic flows on the road network, passenger flows on public transport [5-7]. A structured diagram of the main components of the predictive transport model is shown in Fig. 2.

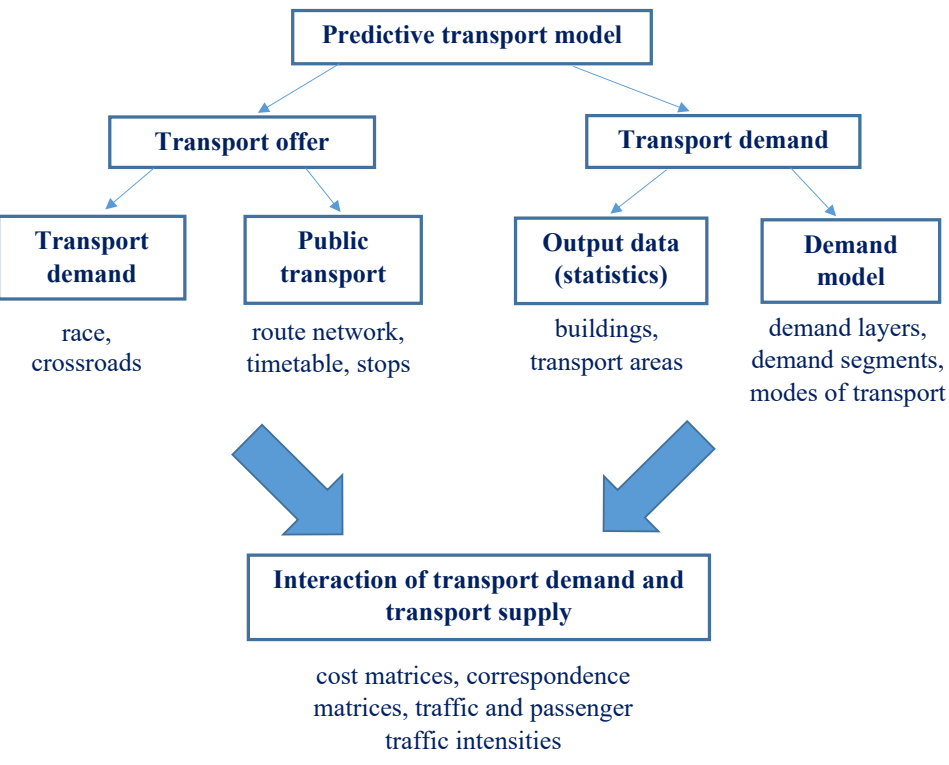

Fig. 2. Structured diagram of the main components of predictive transport model

The first stage in the development of a city's transport model is the creation of a transport proposal, which is represented by the street and road network, traffic intensity, race capacity, public transport routes, etc. [8, 9].

Calculating transport demand using the classic fourstep mathematical model is the second step. The initial data for this is information on the number of population, jobs, the number of schoolchildren and students, places in educational institutions, statistical data on the distribution of transport correspondence by purpose of travel. The transport model is designed to determine the volume of transport work at known locations of the flow-generating objects of the city $[9,10]$.

\section{Research results and discussion}

ITS provides for a variant design of the city's transport system. During its development, a predictive transport model was created, on which several options for the development of the transport system were tested. The options differ in the length of the construction of new main streets, the number of road junctions at different levels and overpasses across the railway, the number of new transport crossings across the Dnipro, the length of high-speed outside street transport lines and the routing of ground public transport routes. The 
analysis of the simulation results was carried out according to the following parameters: the average speed of traffic flow, total transport delays, the total number of passengers transported by public transport, the average distance of travel, the average time for the implementation of transport correspondence on public transport, etc.

Based on the simulation results, the optimal option for the development of the city's transport system was selected. Overall transport delays were $8 \%$ less than other options, and the average transport speed was $25.6 \mathrm{~km} / \mathrm{h}$. The savings in unproductive time losses per day amounted to approximately 3 million USD.

It provides for the completion of the construction of the Podol bridge crossing, the extension of the Big Ring Road to Bohatyrska Street, the construction of more than 10 transport interchanges at different levels. The development of the public transport system is envisaged, in particular the construction of the Podolsko-Vygurivska metro line, the construction of five stopping points on the city train line, the extension of the tram line to the Palats Sportu metro stations, and the development of the trolleybus and bus network.

Table 1 shows the predicted traffic intensity at bridge crossings across the Dnipro and on sections of the main highways of Kyiv. The data are taken from the transport model of Kyiv.

The transport model allows to analyze the change in the predicted intensity of traffic flows on the backbone network. With the development of the transport system, the value of traffic intensity in some areas changes significantly. So, for example, on the section of Povitroflotskyy prospect the intensity for the future is growing by about $25 \%$. At that time, on Shukhevych Avenue decreased by $10 \%$.

\begin{tabular}{|c|c|c|c|c|}
\hline \multirow[b]{2}{*}{ No. } & \multirow{2}{*}{$\begin{array}{l}\text { Name of the section of the road network } \\
\text { Bridge crossings across the river. }\end{array}$} & \multicolumn{3}{|c|}{ Traffic intensity, thousand units per day } \\
\hline & & $\begin{array}{c}\text { Stage } \\
7 \text { years }\end{array}$ & $\begin{array}{c}\text { Stage } \\
20 \text { years }\end{array}$ & $\begin{array}{l}\text { Stage } \\
40-50 \text { years }\end{array}$ \\
\hline 1 & Northern & 124.8 & 121.8 & 98.4 \\
\hline 2 & Paton & 168.8 & 135.1 & 110.3 \\
\hline 3 & Southern & 181.2 & 144.3 & 114.9 \\
\hline- & Main thoroughfares of the city & - & - & - \\
\hline 4 & $\begin{array}{l}\text { Great Ring Road: } \\
\text { - from Minsk Avenue to Miska Street }\end{array}$ & 59.4 & 87.5 & 81.2 \\
\hline 5 & $\begin{array}{l}\text { Small semi-circular road: } \\
\text { - from Borshchahivska Street to Sevastopol Square }\end{array}$ & 58.4 & 40.1 & 35.3 \\
\hline 6 & $\begin{array}{l}\text { Peremohy Ave.: } \\
\text { - from Shcherbakivska to Dehtiarivska Street }\end{array}$ & 178.4 & 142.9 & 109.6 \\
\hline 7 & $\begin{array}{l}\text { Povitroflotskyy Avenue: } \\
\text { - from Solomenska Square to Borshchahivska Street }\end{array}$ & 55.6 & 34.3 & 73.6 \\
\hline 8 & $\begin{array}{l}\text { Holosiivsky Avenue: } \\
\text { - fram Vasylkivska Street to Holosiivska Square }\end{array}$ & 72.3 & 109.3 & 81.4 \\
\hline 9 & $\begin{array}{l}\text { Shukhevych Avenue: } \\
\text { - from Bratyslavska to Perova Steet }\end{array}$ & 51.9 & 80.2 & 46.8 \\
\hline 10 & $\begin{array}{l}\text { Brovarsky Avenue: } \\
\text { - from Bratyslavska to Vyzvolyteliv Street }\end{array}$ & 82.7 & 45.8 & 36.4 \\
\hline 11 & $\begin{array}{l}\text { Bazhan Avenue: } \\
\text { - from Kharkivska Square to Revutsky Street }\end{array}$ & 140.9 & 114.4 & 93.4 \\
\hline
\end{tabular}

\section{Conclusions}

The complex scheme of transport of the city of Kyiv, using modern technologies in the field of transport modeling, is considered in the work. It is a strategic planning document. This document allows to analyze and determine the effectiveness of the implementation of various measures for the development of the city's transport infrastructure in the future. As part of the work, a modern predictive transport model was developed based on the PTV Visum software package, which is widely used in Europe in the field of transport planning. The transport model as part of an integrated transport scheme is a powerful tool that provides data on the volume of transport work, passenger flows, and the like. Based on the results of modeling, during the study, the optimal option for the development of the city's transport system was selected. Overall transport delays were $8 \%$ less than other options, and the savings in overhead time per day amounted to approximately 3 million USD

This transport model can be useful in the field of scientific transport research in predicting the traffic intensity on the road network. And also when analyzing the parameters of traffic flows on the approaches to the largest cities and the like.

The results of the study can be used for future projects at the micro level, in particular, to improve the operation of traffic lights, the arrangement of one-way streets, the justification of separate lanes for public transport. And also, they will help to study the effect of blocking the carriageway of streets during various events in order to predict the redistribution of traffic flows and the like.
Table 1

eferences

1. Iliashenko, O., Iliashenko, V., Lukyanchenko, E. (2021). Big Data in Transport Modelling and Planning. Transportation Research Procedia, 54, 900-908. doi: http://doi.org/10.1016/j.trpro.2021. 02.145

2. Kuzmich, S. I., Fedina, T. O. (2015). Transport problems of modern cities and modeling of the load of the street-road network. Izvestiya TulGU. Technical science, 3.

3. Instytut Heneralnoho planu mista Kyieva (2020). Osnovni polozhennia Heneralnoho planu mista Kyieva. Available at: https:// drive.google.com/drive/u/0/folders /0B xbGBoNdb1j6fmdGWVdtNzJSaWgyTXlWaW5WX1FxV3dSVlVEd1VwYm1UcF8wOVBhUUtmSnM? resourcekey $=0-\mathrm{kPB}$ rifL1pMBULovqoM4QA

4. Klinkovshteyn, G. Y. (1981). Organizat syya dorozhnogo doyzheniya. Moscow: Transport, 240.

5. PTV Group. VISUM 12.5 Fundamentals, VISUM 12.5 Manual, 2012 PTV AG, Karlsruhe. Available at: http://www. ptvgroup.com

6. Lovrić, M., Blainey, S., Preston, J. (2017). A conceptual design for a national transport model with cross-sectoral interdependencies. Transportation Research Procedia, 27, 720-727. doi: http://doi.org/ 10.1016/j.trpro.2017.12.150

7. Yakimov, M. R. (2013). Transportnoe planirovanie: sozdanie transportnykh modeley gorodov. Moskva: Logos, 188. 
8. Papageorgiou, M. (1998). Some remarks on macroscopic traffic flow modelling. Transportation Research Part A: Policy and Practice, 32 (5), 323-329. doi: http://doi.org/10.1016/s09658564(97)00048-7

9. Yakimov, M. R., Popov, Yu. A. (2014). Transportnoe planirovanie: prakticheskie rekomendatsii po sozdaniyu transportnykh modeley gorodov v programmnom komplekse PTV Visum. Moscow: Logos, 200.

10. Ngoduy, D., Hoogendoorn, S. P., van Lint, J. W. C. (2005). Modeling Traffic Flow Operation in Multilane and Multiclass Urban Networks. Transportation Research Record: Journal of the
Transportation Research Board, 1923 (1), 73-81. doi: http:// doi.org/10.1177/0361198105192300108

Oleksandra Humeniuk, Postgraduate Student, Department of Trans port Systems and Road Safety, National Transport University, Kyiv, Ukraine, e-mail: oleksandra27@online.ua, ORCID: https://orcid.org/ 0000-0001-5543-5229

Oleksij Shapovalov, Head of Department, Transport Infrastructure Department, Municipal Organization «Kyivgenplan», Kyiv, Ukraine, e-mail: aleksei86@bigmirnet, ORCID: https://orcid.org/0000-0003-3991-6916

\section{Ramazan Khabutdinov, SIMULATION ANALYSIS OF $\begin{array}{ll}\text { Tatiana Kostiuk } & \text { TRANSPORT ENERGY EFFICIENCY OF } \\ & \text { ROAD TRAINS AND INTERNATIONAL }\end{array}$ TRANSPORT ENERGY EFFICIENCY OF
ROAD TRAINS AND INTERNATIONAL MOTOR TRANSPORTATIONS}

UDC 656.073:656.136

DOI: $10.15587 / 2706-5448.2021 .235554$

Article type «Reports on Research Projects»

The object of the study is the production and technological processes of international road transport (PTP IRT) according to the innovative approach and the conceptual idea of technical and technological energy saving in motor transport. Predictive assumptions about the development of the object of study - the realization of the possibilities of operational-simulation and technical-evolutionary method of complex analysis of transport energy efficiency of road trains and production and technological processes of international road transport in the practice of international road transport.

In the course of the research the operational-simulation and technical-evolutionary method of complex analysis of transport energy efficiency of road trains and production-technological processes of international road transportations was considered. As an example, the influence of changes in such a design parameter of the road train as the gear ratio of the main transmission of the tractor on its transport energy efficiency, as well as fuel and energy consumption of the road train DAF FTR-95xF (Netherlands) in the test trunk operation (at $\alpha_{g}=0$ ). It is established that when the value of the gear ratio of the main transmission $\left(U_{o}\right)$ increases, the value of the energy efficiency indicator $\left(P_{e}\right)$ varies from 0.55 to 0.58 . The greatest value of energy efficiency is at $U_{o}=2.846$. It is determined that when the value of the gear ratio of the main transmission $\left(U_{0}\right)$ increases, the value of the energy consumption indicator $\left(A_{c}\right)$ increases, and the minimum value of $3.2 \mathrm{MJ}$ acquires the value of the gear ratio of the main transmission - 2.846. It was found that when the value of the gear ratio of the main gear $\left(U_{o}\right)$ increases the fuel consumption $\left(Q_{c}\right)$ increases and acquires a maximum value of $3496.84 \mathrm{~g}$ with the value of the gear ratio of the main gear - 4.39. The minimum value of fuel consumption of $1684.2 \mathrm{~g}$ is achieved when the value of the gear ratio of the main transmission 2.846 .

The results of the study can be used to implement systemic and conceptual innovation management in the field of international road transport.

Keywords: conceptual idea, simulation analysis, road transport of international road transport, structure of motor transport, design and road factors.

\section{How to cite}

Khabutdinov, R., Kostiuk, T. (2021). Simulation analysis of transport energy efficiency of road trains and international motor transportations. Technology Audit and Production Reserves, 3 (2 (59)), 54-57. doi: http://doi.org/10.15587/2706-5448.2021.235554

\section{Introduction}

Road trains that are used for international freight transport today represent a wide range of automotive equip- ment, which is constantly updated and which has a number of requirements (resource conservation, environmental friendliness, fuel efficiency, etc.). When substantiating the renewal of the fleet of road trains, it is necessary to take 